\title{
Composition of Mycolic Acid Molecular Species as a Criterion in Nocardial Classification
}

\author{
TUNEKO BABA, ${ }^{*}$ YUKIKO NISHIUCHI, ${ }^{2}$ AND IKUYA YANO ${ }^{2}$ \\ Department of Domestic Science, Kobe Shoin Women's College, Kobe 657, ${ }^{1}$ and Department of \\ Bacteriology, Osaka City University Medical School, Osaka 545, Japan
}

\begin{abstract}
By using gas chromatography and gas chromatography-mass spectrometry, we analyzed the mycolic acid compositions of 18 strains of Nocardia asteroides, 17 strains of Nocardia farcinica, and 17 strains of Nocardia nova classified by numerical taxonomy. These organisms had characteristic mycolic acid compositions. We calculated the peak areas of the molecular species of mycolic acids on gas chromatograms and determined the average total carbon number in each strain. The strains of $N$. asteroides were divided into five groups, and the type strain belonged to group $\mathrm{C}_{54}$. The strains of $N$. farcinica were divided into three groups, and the type strain was in group $\mathrm{C}_{53}$. On the other hand, the strains of $N$. nova differed distinctly from the other two species and belonged mainly to groups $C_{56}$ and $C_{57}$. Our detailed analysis of mycolic acids was simple and precise. Therefore, the use of this method should be encouraged more for nocardial classification in combination with DNA or RNA analysis.
\end{abstract}

For a long time classification of the genus Nocardia has been a major issue in the taxonomy of the order Actinomycetales. In particular, the chemotaxonomy of Nocardia asteroides and related species has been confused for decades. Goodfellow stated that Nocardia farcinica was a good taxospecies, but $N$. asteroides was markedly heterogeneous based on numerical taxonomy data $(9,26)$. After this, a new species, Nocardia nova, was differentiated from a subgroup of $N$. asteroides, was proposed by Tsukamura et al. (27), and was characterized on the basis of numerical (27) and chemotaxonomic (31) analysis data. The taxonomy of $N$. asteroides and $N$. farcinica was still a difficult issue. Recently, the yeast killer system (20), ribotyping encoded by $16 \mathrm{~S}$ rRNA $(6,16)$, antibiotic sensitivity (28), and opacification of Middlebrook agar (8) have been used to differentiate these three Nocardia species.

Mycolic acids are unique high-molecular-weight 3-hydroxyl fatty acids with long alkyl chains at position 2 and are characteristic cell wall constituents of Mycobacterium (3, 4, 11, 12, 14, 17), Nocardia $(2,30)$, Rhodococcus $(1,2)$, Gordona (1), Corynebacterium (7, 29), Tsukamurella (10), and Dietzia (21) species. Since the mycolic acid subclass or molecular species compositions vary greatly among taxa, mycolic acids are good markers for differentiating genera or species. However, characteristics used for classification in most previous studies were total carbon number, the number of double bonds, and the acids released by pyrolysis of mycolic acids. Previously, we developed an analytical method for whole mycolic acids without pyrolysis in which trimethylsilylated (TMS) ether derivatives were used for gas chromatography (GC) and gas chromatography-mass spectrometry (GC-MS) $(3,4,11,12,29,30)$. We utilized the average carbon number and the length of the $\alpha$-branch obtained by this method to classify taxa.

We have many Nocardia strains which were classified as $N$. asteroides, $N$. farcinica, and $N$. nova strains by numerical methods by M. Tsukamura. Since there is strong evidence that $N$. asteroides is heterogeneous and that $N$. asteroides is closely related to $N$. farcinica, we investigated the mycolic acid com-

\footnotetext{
* Corresponding author. Mailing address: Department of Domestic Science, Kobe Shoin Women's College, 1-2-1, Shinohara-Obanoyamacho, Nada-ku, Kobe 657, Japan. Phone: 81-78-882-6122. Fax: 81-78$882-4627$
}

positions of more than 50 strains belonging to $N$. asteroides, $N$. farcinica, and $N$. nova in order to classify them on the basis of chemical taxonomy data.

\section{MATERIALS AND METHODS}

All of the Nocardia strains were divided preliminarily on the basis of the results of a numerical analysis (27) and were supplied by M. Tsukamura, National Chubu Hospital (Obu, Aichi, Japan). The Nocardia strains which we used are shown in Table 1 . Each strain was grown in medium containing $1 \%$ glucose, $0.5 \%$ peptone, and $0.2 \%$ yeast extract with the $\mathrm{pH}$ adjusted to 7.2 at $37^{\circ} \mathrm{C}$ for 3 to 7 days on a rotary shaker.

Mycolic acids were extracted and separated as described previously (4). $\alpha$-Mycolic acid methyl esters were separated by preparative thin-layer chromatography on silica gels and were trimethylsilylated with $\mathrm{N}, \mathrm{O}$-bis-(trimethylsilyl)trifluoroacetamide-pyridine $(1: 2, \mathrm{vol} / \mathrm{vol})$ at $80^{\circ} \mathrm{C}$ for $30 \mathrm{~min}$.

The numbers of carbon atoms and double bonds were determined by GC and GC-MS. To separate each molecular species of mycolic acid that differed in carbon number, GC was performed with a Shimadzu model GC-9A instrument equipped with a column packed with $1 \%$ OV-1 or a capillary column $(0.53 \mathrm{~mm}$ by $15 \mathrm{~m}$ ) coated with $5 \%$ methyl phenyl silicone. The column temperature was programmed to increase from 300 to $330^{\circ} \mathrm{C}$ at a rate of $1^{\circ} \mathrm{C} / \mathrm{min}$. Mass spectrometry and mass chromatography were carried out with a Hitachi model M-80 instrument. The ion source energy was $20 \mathrm{eV}$, and the accelerating voltage was $3 \mathrm{kV}$. Detailed conditions have been described previously (11). Every analysis was performed at least in duplicate. The peak areas of molecular species were calculated by the vertical division method. The average total carbon numbers of mycolic acids were determined from the sum of the products of the carbon numbers multiplied by the percent compositions.

\section{RESULTS}

GC profiles of TMS methyl mycolates of strains of Nocardia species. The total fatty acid methyl esters from each Nocardia species produced two spots on thin-layer chromatograms. The upper spot corresponded to nonpolar fatty acid methyl esters. The lower spot, with an $R_{f}$ value of 0.5 to 0.6 , corresponded to $\alpha$-mycolic acid esters. Thus, the Nocardia species, with one subclass of mycolic acids ( $\alpha$-mycolic acids), differed from $M y$ cobacterium species.

$\alpha$-Mycolic acid methyl esters were converted to TMS ether derivatives and were analyzed by GC or GC-MS. Figure 1 shows typical gas chromatograms of TMS ether derivatives of $\alpha$-mycolic acid methyl esters from the $N$. asteroides, $N$. farcinica, and $N$. nova strains. Each strain produced six to nine peaks corresponding to $\mathrm{C}_{40}$ to $\mathrm{C}_{62}$ mycolic acids, as judged from the mass spectrometric analysis and the relationship between $\log$ retention time and carbon number on gas chromato- 
TABLE 1. Nocardia strains used in this study

\begin{tabular}{|c|c|c|}
\hline Laboratory no. & Designation(s) & Source \\
\hline \multicolumn{3}{|c|}{ N. asteroides strains } \\
\hline 23008 & M123 & M. Tsukamura $\leftarrow$ I. Uesaka $\leftarrow$ N. M. McClung \\
\hline 23019 & M78 & M. Tsukamura $\leftarrow$ I. Uesaka $\leftarrow$ N. M. McClung \\
\hline 23046 & M129 & M. Tsukamura $\leftarrow$ I. Uesaka $\leftarrow$ N. M. McClung \\
\hline 23049 & M132 & M. Tsukamura $\leftarrow$ I. Uesaka $\leftarrow$ N. M. McClung \\
\hline 23064 & M161 & M. Tsukamura $\leftarrow$ I. Uesaka $\leftarrow$ N. M. McClung \\
\hline 23094 & ATCC 23824, R399 & M. Tsukamura $\leftarrow$ R. E. Gordon \\
\hline 23099 & R860 & M. Tsukamura $\leftarrow$ R. E. Gordon \\
\hline 23169 & N9 & M. Tsukamura $\leftarrow$ K. P. Schaal \\
\hline 23170 & N10 & M. Tsukamura $\leftarrow$ K. P. Schaal \\
\hline 23172 & N14 & M. Tsukamura $\leftarrow$ K. P. Schaal \\
\hline 23173 & N15 & M. Tsukamura $\leftarrow$ K. P. Schaal \\
\hline 23175 & N57 & M. Tsukamura $\leftarrow$ K. P. Schaal \\
\hline 23182 & N13 & M. Tsukamura $\leftarrow$ M. Goodfellow \\
\hline 23183 & N317 & M. Tsukamura $\leftarrow$ M. Goodfellow \\
\hline 23189 & N669 & M. Tsukamura $\leftarrow$ M. Goodfellow \\
\hline 23203 & & M. Tsukamura; sputum, human \\
\hline 23205 & & M. Tsukamura; sputum, human \\
\hline $23206^{\mathrm{T}}$ & ATCC $19247^{\mathrm{T}}$ & M. Tsukamura $\leftarrow$ I. J. Bousfield \\
\hline \multicolumn{3}{|c|}{ N. farcinica strains } \\
\hline 23004 & M72 & M. Tsukamura $\leftarrow$ I. Uesaka $\leftarrow$ N. M. McClung \\
\hline 23013 & M146 & M. Tsukamura $\leftarrow$ I. Uesaka $\leftarrow$ N. M. McClung \\
\hline 23055 & M146 & M. Tsukamura $\leftarrow$ I. Uesaka $\leftarrow$ N. M. McClung \\
\hline 23087 & ATCC 23826, M205 & M. Tsukamura $\leftarrow$ I. Uesaka $\leftarrow$ N. M. McClung \\
\hline 23101 & W3409B & M. Tsukamura $\leftarrow$ R. E. Gordon \\
\hline 23102 & ATCC 3318, R3318 & M. Tsukamura $\leftarrow$ R. E. Gordon \\
\hline $23157^{\mathrm{T}}$ & ATCC $3318^{\mathrm{T}}$ & M. Tsukamura $\leftarrow$ M. P. LeChevalier \\
\hline 23162 & & M. Tsukamura; pleural pus, human \\
\hline 23163 & & M. Tsukamura; pleural pus, human \\
\hline 23164 & & M. Tsukamura; sputum, human \\
\hline 23165 & & M. Tsukamura; sputum, human \\
\hline 23166 & N1 & M. Tsukamura $\leftarrow$ K. P. Schaal \\
\hline 23167 & N6 & M. Tsukamura $\leftarrow$ K. P. Schaal \\
\hline 23168 & N7 & M. Tsukamura $\leftarrow$ K. P. Schaal \\
\hline 23171 & N12 & M. Tsukamura $\leftarrow$ K. P. Schaal \\
\hline 23201 & & M. Tsukamura; bronchial secretion, human \\
\hline E12618 & & M. Tsukamura $\leftarrow$ H. Shimode; human \\
\hline \multicolumn{3}{|l|}{ N. nova strains } \\
\hline 23006 & M93 & M. Tsukamura $\leftarrow$ I. Uesaka $\leftarrow$ N. M. McClung \\
\hline 23012 & M145 & M. Tsukamura $\leftarrow$ I. Uesaka $\leftarrow$ N. M. McClung \\
\hline 23032 & M10 & M. Tsukamura $\leftarrow$ I. Uesaka $\leftarrow$ N. M. McClung \\
\hline 23038 & M93 & M. Tsukamura $\leftarrow$ I. Uesaka $\leftarrow$ N. M. McClung \\
\hline 23044 & M124 & M. Tsukamura $\leftarrow$ I. Uesaka $\leftarrow$ N. M. McClung \\
\hline 23088 & M206 & M. Tsukamura $\leftarrow$ I. Uesaka $\leftarrow$ N. M. McClung \\
\hline $23095^{\mathrm{T}}$ & ATCC $33726^{\mathrm{T}}, \mathrm{R} 443(1)^{\mathrm{T}}$ & M. Tsukamura $\leftarrow$ R. E. Gordon \\
\hline 23096 & $\mathrm{R} 443$ (2) & M. Tsukamura $\leftarrow$ R. E. Gordon \\
\hline 23103 & ATCC 9970 & M. Tsukamura $\leftarrow$ R. E. Gordon \\
\hline 23174 & $\mathrm{~N} 23$ & M. Tsukamura $\leftarrow$ K. P. Schaal \\
\hline 23177 & N229 & M. Tsukamura $\leftarrow$ K. P. Schaal \\
\hline 23181 & E9 & M. Tsukamura $\leftarrow$ M. Goodfellow \\
\hline 23192 & N692 & M. Tsukamura $\leftarrow$ M. Goodfellow \\
\hline 23196 & N878 & M. Tsukamura $\leftarrow$ M. Goodfellow \\
\hline 23204 & ATCC 33727 & M. Tsukamura; sputum, human \\
\hline 23209 & ATCC 33726 & M. Tsukamura; human \\
\hline 23210 & ATCC 33727 & M. Tsukamura; human \\
\hline
\end{tabular}

grams. As shown in Fig. 1, the largest peak for strain 23206, the type strain of $N$. asteroides, was the $\mathrm{C}_{54}$ peak. On the other hand, the gas chromatogram obtained for strain 23094 revealed that $\mathrm{C}_{52}$ was the main component. The chromatogram obtained for strain 23064 contained two major mycolic acid peaks $\left(\mathrm{C}_{52}\right.$ and $\left.\mathrm{C}_{54}\right)$. The mycolic acids of strains 23099 and 23019 differed completely from the mycolic acids of other $N$. asteroides strains, and the most abundant components were around $\mathrm{C}_{48}$ and $\mathrm{C}_{44}$, respectively. On the other hand, for the type strain of $N$. farcinica, 23157, the most abundant species of mycolic acids was $\mathrm{C}_{54}$ on gas chromatograms, and the secondary peak was $\mathrm{C}_{52}$. Many other $N$. farcinica strains produced almost the same GC profile as strain $23157^{\mathrm{T}}$. For another $N$. farcinica strain tested, strain 23013, the major peak was $C_{52}$, and the secondary peak was $\mathrm{C}_{54}$. In contrast to $N$. asteroides and $N$. farcinica, the mycolic acid profiles of all of the $N$. nova 


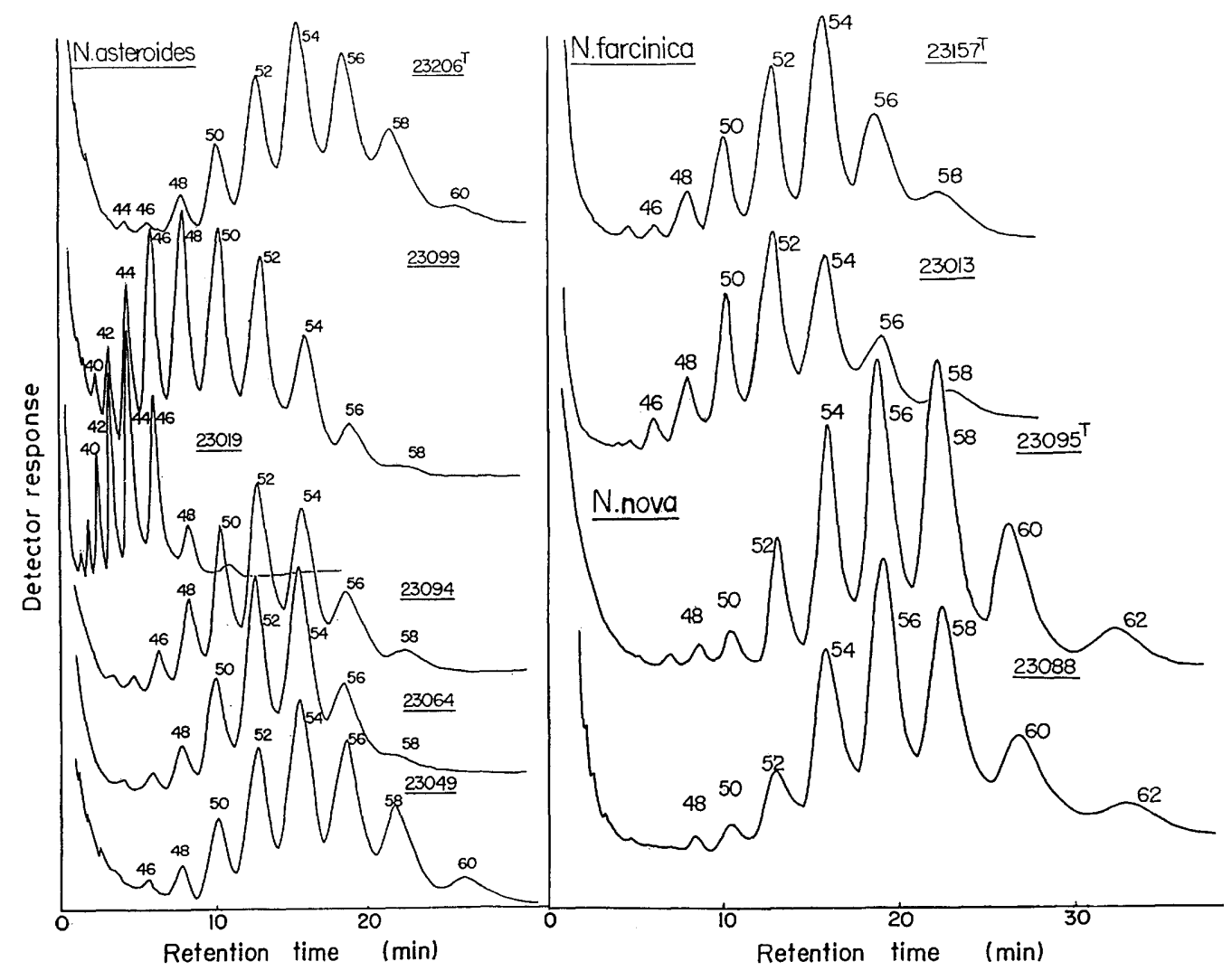

FIG. 1. GC analysis of TMS methyl mycolates from several strains of three Nocardia species (N. asteroides, N. farcinica, and N. nova). The number for each peak indicates the total number of carbon atoms in the mycolic acid.

tested (including $23095^{\mathrm{T}}$ and 23088) revealed that $\mathrm{C}_{56}$ and $\mathrm{C}_{58}$ mycolic acids were the most abundant components.

Differentiation of three Nocardia species based on the total carbon and double bond numbers of mycolic acids. GC-MS revealed the more detailed structures of the individual mycolic acid molecules. Figure 2 shows mass spectra of TMS derivatives of methyl mycolates of $N$. asteroides 23094, $N$. farcinica 23190, and N. nova 23177. As Fig. 3 shows, general fragmentation of TMS methyl mycolates during electron impact mass spectrometry yielded characteristic ions useful for identification. The molecular ion $[\mathrm{M}]^{+}$was usually weak, but $[\mathrm{M}-15]^{+}$ ions (loss of $\mathrm{CH}_{3}$ ) were generally abundant and could be used to establish molecular weight. Fission of the intraalkyl chain $\left(\mathrm{C}_{2}-\mathrm{C}_{3}\right)$ gave the fragment ion $[\mathrm{A}]^{+}$. This ion was useful for determining the straight-chain alkyl moieties of the original mycolic acids. In contrast, cleavage between $\mathrm{C}_{3}$ and $\mathrm{C}_{4}$ resulted in fragment ion $[\mathrm{B}]^{+}$, which was useful for identifying the $\alpha$-branched chain structure of mycolic acids. In $N$. asteroides, the presence of $[\mathrm{M}-15]^{+}$corresponding to $\mathrm{C}_{44}$ to $\mathrm{C}_{58}$ mycolic acids having zero to three double bonds was clearly demonstrated, and the mycolic acids with longer chains tended to have more double bonds. For $\mathrm{C}_{52}$ mycolic acids, the most abundant $[\mathrm{M}-15]^{+}$ions were observed at $m / e 843$ and 845 , corresponding to $\mathrm{C}_{52: 2}$ and $\mathrm{C}_{52: 1}$ mycolates, respectively. A similar $[\mathrm{M}-15]^{+}$ion was observed in the $\mathrm{C}_{52}$ mycolate of $N$. farcinica, and in the $\mathrm{C}_{54}$ mycolate of the same organism, the $[\mathrm{M}-15]^{+}$ion was shifted up by 28 mass units to $m / e 871$ due to $\mathrm{C}_{54: 2}$. On the other hand, in $N$. nova, the major mycolic acid molecules had another double bond in the $\alpha$-branch. The most abundant molecular component was $\mathrm{C}_{56}$ or $\mathrm{C}_{58}$ mycolate and was a mixture of triene and tetraene subclasses.
Comparison of the detailed molecular structures of the mycolic acids of three Nocardia species. Another characteristic of the mycolic acids was the presence of both a straight-chain alkyl unit and an $\alpha$-branched chain in the three Nocardia species. As shown in Fig. 2, a certain mycolic acid of $N$. asteroides usually consisted of a mixture of two or more molecules differing in the $\alpha$-alkyl branch and the straight-chain unit. In the $\mathrm{C}_{52}$ mycolate of $N$. asteroides, at least two kinds of $[\mathrm{A}]^{+}$fragment ions were clearly found at $m / e 591$ and 617 due to $\mathrm{C}_{36: 1}$ and $\mathrm{C}_{38.2}$ straight alkyl chains, respectively, and also two $[\mathrm{B}]^{+}$ fragment ions were at $m / e 371$ and 343 due to $\mathrm{C}_{16: 0}$ and $\mathrm{C}_{14: 0}$ $\alpha$-alkyl branches, respectively. Therefore, the $\mathrm{C}_{52}$ mycolate of $N$. asteroides was a mixture of a $\mathrm{C}_{36: 1}$ straight chain with a $\mathrm{C}_{16: 0}$ $\alpha$-branch and a $\mathrm{C}_{38: 2}$ straight chain with a $\mathrm{C}_{14: 0} \alpha$-branch. Similar results were obtained for the $\mathrm{C}_{48}$ to $\mathrm{C}_{54}$ mycolates of $N$. asteroides. In contrast, in the case of $N$. farcinica, the $[\mathrm{A}]^{+}$ fragment ion of each mycolate produced a single peak, and therefore the $[\mathrm{B}]^{+}$fragment ion was also a single compound. Thus, the $\mathrm{C}_{52}$ mycolate of $N$. farcinica was a simple molecule with a $C_{36: 1}\left(C_{36: 2}\right)$ straight chain and a $C_{16: 0} \alpha$-branch. On the other hand, we also noted that the molecular species composition of $N$. nova was much more complicated than the molecular species compositions of $N$. asteroides and $N$. farcinica. As shown in Fig. 2, $\mathrm{C}_{58}$ mycolate $\left(\mathrm{C}_{58: 3}\right.$ and $\left.\mathrm{C}_{58: 4}\right)$ was a mixture of molecular species in at least four combinations $\left(\mathrm{C}_{40: 2}\right.$ plus $\mathrm{C}_{18: 1}, \mathrm{C}_{40: 3}$ plus $\mathrm{C}_{18: 0}, \mathrm{C}_{42: 3}$ plus $\mathrm{C}_{16: 0}$, and $\mathrm{C}_{40: 3}$ plus $\mathrm{C}_{18: 1}$ ). However, we especially noted that the $N$. nova mycolates had abundant $\mathrm{C}_{18: 1}$ (and $\mathrm{C}_{18: 0}$ ) $\alpha$-alkyl branches. Thus, they differed from the mycolates of $N$. asteroides and $N$. farcinica.

Grouping based on molecular species composition of mycolic acids in the genus Nocardia. To determine the composi- 

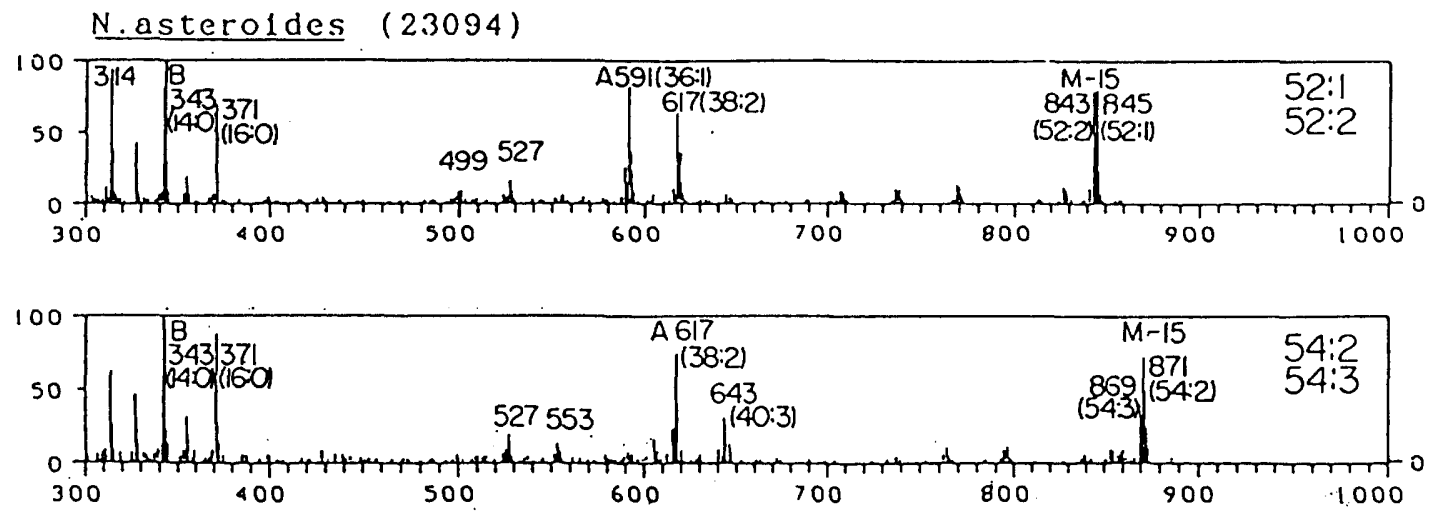

N.farcinica $(23190)$
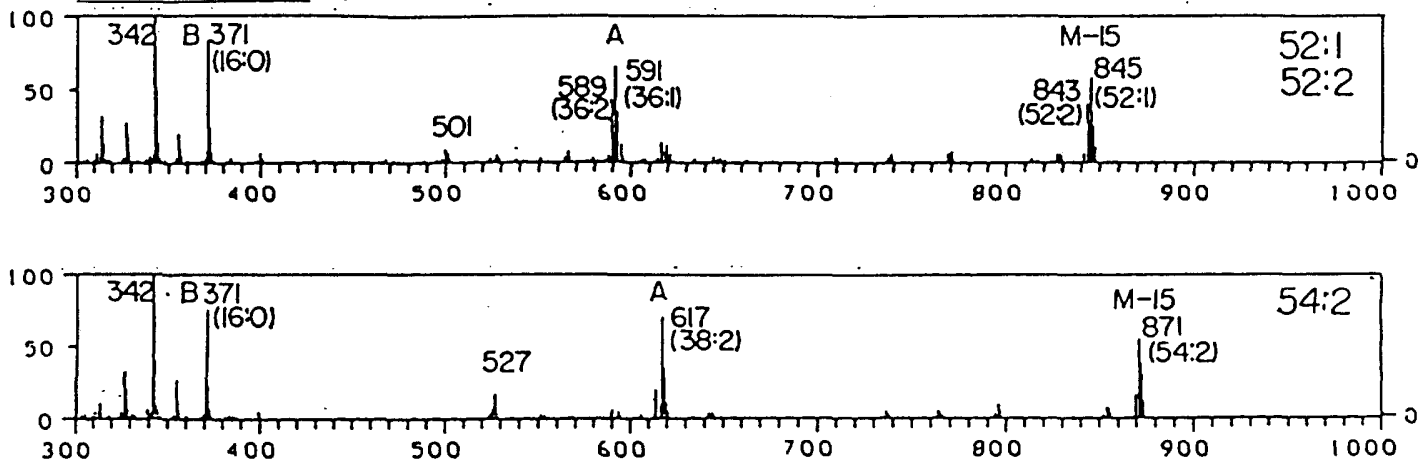

N. nova (23177)
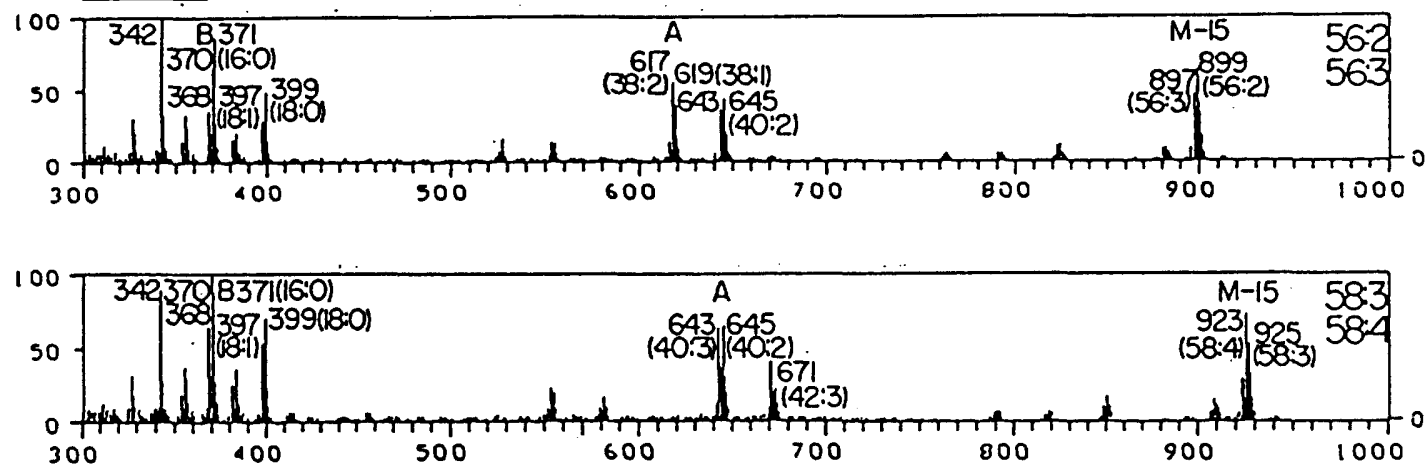

FIG. 2. Mass spectra of TMS derivatives of methyl mycolates of N. asteroides 23094, N. farcinica 23190 , and N. nova 23177 .

tions of mycolic acid molecular species, we calculated the peak areas on gas chromatograms. The ratio of each molecular species to the total mycolic acids is shown in Table 2. The largest peaks accounted for more than $25 \%$ (nearly $30 \%$ ) of the total area. The average total carbon numbers for mycolic acids are also shown in Table 2 . All of the strains were classified on the basis of the average total carbon number in the mycolic acids of the strains belonging to the same species (Table 3). Eighteen strains of $N$. asteroides identified by numerical taxonomy were separated into the following five groups: groups $\mathrm{C}_{\leq 50}, \mathrm{C}_{52}, \mathrm{C}_{53}, \mathrm{C}_{54}$, and $\mathrm{C}_{55}$. Similarly, 17 strains of $N$. farcinica were separated into three groups, groups $\mathrm{C}_{52}, \mathrm{C}_{53}$, and $\mathrm{C}_{54}$. Type strain 23157 of $N$. farcinica was in- cluded in group $\mathrm{C}_{53}$, and $N$. asteroides $23206^{\mathrm{T}}$ was in group $\mathrm{C}_{54}$ Seventeen strains of $N$. nova were also separated into three groups, groups $\mathrm{C}_{55}, \mathrm{C}_{56}$, and $\mathrm{C}_{57}$. All of the $N$. nova strains contained $\mathrm{C}_{56}$ or $\mathrm{C}_{58}$ mycolic acid as the most abundant component.

\section{DISCUSSION}

We analyzed the mycolic acid compositions of more than 50 strains, including the type strains of $N$. asteroides, $N$. farcinica, and $N$. nova, by GC and GC-MS and tried to classify the strains based on their compositions.

Eighteen strains of $N$. asteroides were divided into five 


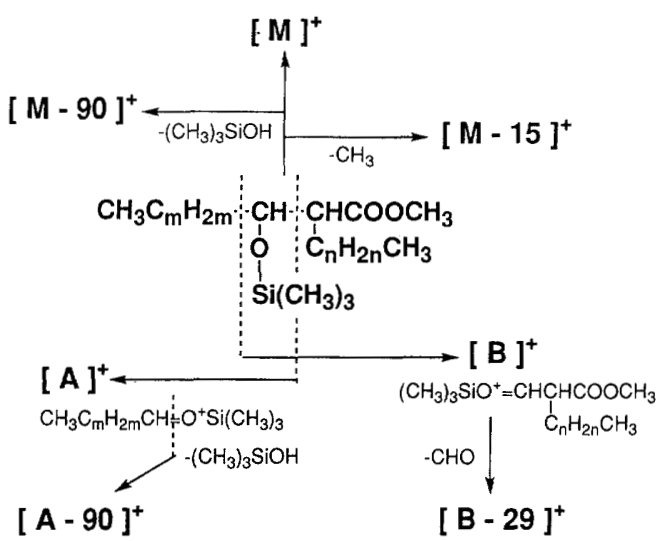

FIG. 3. General fragmentation of TMS derivatives of methyl mycolate during electron impact mass spectrometry.

groups on the basis of the average total carbon numbers (Table 3). Strains 23019 and 23099, members of group $\mathrm{C}_{\leq 50}$, were obviously different from other $N$. asteroides strains, $N$. farcinica, and $N$. nova, as shown by the patterns on gas chromatograms (Fig. 1) and by the major components of their mycolic acids (Table 2). The mycolic acids of Rhodococcus strains contained 34 to 50 carbon atoms (2). Our previous data for Rhodococcus strains revealed a range of 28 to 46 carbon atoms (2). Therefore, it seemed that strains 23019 and 23099 belonged to the genus Rhodococcus even though they were classified as $N$. asteroides strains by the numerical method. This implies that classification by the numerical method alone is not accurate and that the original taxon $N$. asteroides was heterogeneous. Tomiyasu (25) described the mycolic acid compositions of three strains of $N$. asteroides (23006, 23007, and 23094) and showed that these compositions differed distinctly. The type strain of $N$. asteroides (23206) belonged to group $\mathrm{C}_{54}$ in this study. The matching coefficient for strain $23206^{\mathrm{T}}$ with strains 23094 (group $\mathrm{C}_{52}$ ) and 23046 (group $\mathrm{C}_{53}$ ) was $90 \%$ according to previous data $(26,27,31)$. The value for the species was also rather low. The level of DNA complementarity for strains $23206^{\mathbf{T}}$ and 23094 was as low as $18 \%$ (13). The results of DNA amplification with restriction endonuclease analysis (28) and ribotyping (16) also demonstrated that $N$. asteroides strains should be divided into two groups. Immunodiffusion studies revealed that the type strain of $N$. asteroides (ATCC 19247) was clearly distinct from most of the strains of this species (22). Although $N$. asteroides can be identified by various methods and is thought to be an obviously independent Nocardia species, it is still heterogeneous on the basis of mycolic acid composition and other evidence.

We showed previously that matching coefficients for $N$. farcinica strains were greater than $92 \%$ (31), and other authors have also found that $N$. farcinica is a fairly homogeneous taxon $(9,19)$. Eighteen strains of $N$. farcinica were separated into three groups based on mycolic acid composition. Group $\mathrm{C}_{53}$ of $N$. farcinica, including type strain 23157 , contained $\mathrm{C}_{54}$ mycolic acid as a major component. The results (13) of previous DNA relatedness studies showed that the levels of relatedness among the strains belonging to group $C_{53}$ were high. Therefore, group $\mathrm{C}_{53}$ is probably representative of $N$. farcinica.

We noticed that the groups identified on the basis of average total carbon numbers in mycolic acids overlapped between $N$. asteroides and $N$. farcinica, although the type strain groups were different. The results of a DNA reassociation study indicated that the $N$. asteroides strains fell into three DNA homology groups, one of which contained the type strain of $N$. farcinica (18). A phylogenetic analysis of 16S RNA revealed that two sublines could be recognized in the Nocardia clade; $N$. asteroides and $N$. farcinica were members of one subline, while $N$. nova was in the other (6). The overlap of mycolic acid groups observed with the $N$. asteroides and $N$. farcinica strains might mean that these two species are closely related. Differentiation between $N$. asteroides and $N$. farcinica by GC of mycolic acids alone was sometimes very difficult, because the differences in the mycolic acid compositions of the two species are very minor. In this study, using packed-column GC-MS, we did not find obvious differences in the major molecular species of mycolic acids between $N$. asteroides and $N$. farcinica; that is,

TABLE 2. Mycolic acid compositions of Nocardia strains

\begin{tabular}{|c|c|c|c|c|c|c|c|c|c|c|c|c|c|c|}
\hline \multirow[b]{2}{*}{ Species } & \multirow[b]{2}{*}{ Strain } & \multicolumn{12}{|c|}{$\%$ of total mycolic acids } & \multirow{2}{*}{$\begin{array}{l}\text { Avg no. of } \\
\text { C atoms } \\
\text { in mycolic } \\
\text { acids }\end{array}$} \\
\hline & & $\begin{array}{l}\sim 42 \mathrm{C} \\
\text { atoms }\end{array}$ & $\begin{array}{l}44 \mathrm{C} \\
\text { atoms }\end{array}$ & $\begin{array}{c}46 \mathrm{C} \\
\text { atoms }\end{array}$ & $\begin{array}{c}48 \mathrm{C} \\
\text { atoms }\end{array}$ & $\begin{array}{c}50 \mathrm{C} \\
\text { atoms }\end{array}$ & $\begin{array}{c}52 \mathrm{C} \\
\text { atoms }\end{array}$ & $\begin{array}{c}54 \mathrm{C} \\
\text { atoms }\end{array}$ & $\begin{array}{c}56 \mathrm{C} \\
\text { atoms }\end{array}$ & $\begin{array}{c}58 \mathrm{C} \\
\text { atoms }\end{array}$ & $\begin{array}{c}60 \mathrm{C} \\
\text { atoms }\end{array}$ & $\begin{array}{c}62 \mathrm{C} \\
\text { atoms }\end{array}$ & $\begin{array}{c}64 \mathrm{C} \\
\text { atoms }\end{array}$ & \\
\hline \multirow[t]{6}{*}{ N. asteroides } & 23019 & 37.4 & 35.5 & 19.1 & 8.0 & & & & & & & & & 43.6 \\
\hline & 23064 & & 0.1 & 1.6 & 5.9 & 15.0 & 30.7 & 32.4 & 12.3 & 2.1 & 0.2 & & & 52.8 \\
\hline & 23094 & & 0.3 & 4.5 & 10.9 & 20.1 & 26.7 & 24.3 & 10.4 & 2.3 & 0.4 & & & 52.0 \\
\hline & 23099 & 0.6 & 7.3 & 12.8 & 17.4 & 18.9 & 16.8 & 13.5 & 6.8 & 2.8 & & & & 48.4 \\
\hline & 23170 & & & & 1.8 & 9.1 & 18.7 & 33.9 & 25.7 & 9.5 & 2.5 & & & 54.8 \\
\hline & $23206^{\mathrm{T}}$ & & 0.1 & 0.6 & 3.4 & 9.0 & 21.3 & 27.8 & 23.7 & 11.4 & 2.8 & & & 54.1 \\
\hline \multirow[t]{6}{*}{ N. farcinica } & 23013 & & & 2.2 & 6.7 & 15.0 & 29.1 & 27.9 & 13.8 & 2.2 & 0.4 & & & 51.8 \\
\hline & 23055 & & & 0.2 & 2.1 & 7.6 & 21.6 & 36.1 & 26.1 & 5.5 & & & & 54.0 \\
\hline & 23101 & & 0.6 & 7.2 & 12.0 & 20.2 & 28.7 & 23.5 & 6.4 & 1.5 & & & & 51.5 \\
\hline & $23157^{\mathrm{T}}$ & & & 1.2 & 6.9 & 13.8 & 24.8 & 31.9 & 17.1 & 4.2 & 0.8 & & & 53.0 \\
\hline & 23165 & & 2.1 & 4.4 & 6.2 & 10.1 & 16.9 & 23.5 & 21.5 & 5.5 & & & & 53.0 \\
\hline & 23171 & & 0.7 & 3.1 & 5.3 & 14.6 & 28.0 & 30.3 & 15.3 & 4.0 & 0.5 & & & 53.7 \\
\hline \multirow[t]{6}{*}{ N. nova } & 23012 & & & & & 3.1 & 7.1 & 11.7 & 30.5 & 30.5 & 15.3 & 2.0 & & 56.8 \\
\hline & 23088 & & & & 0.8 & 1.9 & 6.2 & 21.7 & 31.3 & 26.1 & 12.0 & & & 56.3 \\
\hline & $23095^{\mathrm{T}}$ & & & & 0.4 & 2.5 & 5.6 & 10.8 & 24.5 & 27.4 & 17.3 & 9.2 & 2.3 & 57.3 \\
\hline & 23103 & & & & & 0.9 & 3.0 & 11.4 & 23.5 & 36.2 & 23.3 & 1.7 & & 57.4 \\
\hline & 23174 & & & & 0.5 & 1.4 & 6.2 & 16.1 & 33.4 & 31.3 & 10.9 & 0.6 & & 57.2 \\
\hline & 23204 & & & & & 1.4 & 4.7 & 14.5 & 29.0 & 32.9 & 14.1 & 3.6 & & 57.0 \\
\hline
\end{tabular}


TABLE 3. Grouping by average total number of carbon atoms in mycolic acids

\begin{tabular}{|c|c|c|c|c|c|c|c|c|}
\hline \multirow{2}{*}{ Species } & \multirow{2}{*}{$\begin{array}{l}\text { No. of } \\
\text { strains }\end{array}$} & \multicolumn{7}{|c|}{ Strains with the following avg total no. of carbon atoms in mycolic acids: } \\
\hline & & $\sim 50$ & 52 & 53 & 54 & 55 & 56 & 57 \\
\hline N. asteroides & 18 & 23019,23099 & 23094,23173 & $\begin{array}{l}23046,23064 \\
23169,23175 \\
23183,23189 \\
23203\end{array}$ & $\begin{array}{l}23008,23049, \\
23182,23206^{\mathrm{T}}\end{array}$ & $\begin{array}{l}23170,23172 \\
23205\end{array}$ & & \\
\hline N. farcinica & 17 & & $\begin{array}{l}23013,23101 \\
23166\end{array}$ & $\begin{array}{l}23004,23087, \\
23102,23157^{\mathrm{T}}, \\
23162,23163, \\
23164,23165, \\
23167,23168, \\
23201\end{array}$ & $\begin{array}{l}23055,23171 \\
\text { E12618 }\end{array}$ & & & \\
\hline N. nova & 17 & & & & & 23038,23044 & $\begin{array}{l}23006,23032, \\
23088,23096, \\
23177,23181, \\
23210\end{array}$ & $\begin{array}{c}23012,23095^{\mathrm{T}} \\
23103,23174, \\
23192,23196 \\
23204,23209\end{array}$ \\
\hline
\end{tabular}

both $N$. asteroides and $N$. farcinica had $\mathrm{C}_{54}$ mycolic acids with $\mathrm{C}_{16: 0} \alpha$-chains as the most abundant molecular species (range, $\mathrm{C}_{44}$ to $\mathrm{C}_{58}$ with zero to three double bonds).

Seventeen strains of $N$. nova had $\mathrm{C}_{56}$ or $\mathrm{C}_{58}$ mycolic acids (total carbon numbers) with $\mathrm{C}_{16: 0}, \mathrm{C}_{18: 0}$, or $\mathrm{C}_{18: 1} \alpha$-chains (range, $\mathrm{C}_{50}$ to $\mathrm{C}_{62}$ with zero to four double bonds). The mycolic acid composition of $N$. nova was clearly different from the mycolic acid compositions of the other two species. Consequently, our data revealed that $N$. nova is a good species that can be distinguished from $N$. asteroides and $N$. farcinica. This finding was supported by the results of other studies, such as DNA complementarity $(31), 16 \mathrm{~S}$ rRNA $(6,16)$, antibiotic sensitivity (28), opacification of Middlebrook agar (8), and detection of preformed enzyme (5) studies.

GC-MS analysis was very effective because it gave precise information concerning the structure of the $\alpha$-branch and straight alkyl chain unit of mycolic acids with a small amount of sample. The grouping by average total carbon numbers of mycolic acid coincided well with the results of a DNA hybridization study. Biosynthesis of mycolic acids is thought to include many enzymatic steps that are performed by complex multienzyme systems $(15,23,24)$. Therefore, we suppose that the mycolic acid structure is determined by the bulk of genes. A taxonomy based on mycolic acid composition would be more consistent with a taxonomy based on genetic characteristics than with a taxonomy based on numerical phenetic characteristics. Mycolic acid analysis by GC-MS combined with DNA or RNA analysis appears to be sufficient for definite identification of Nocardia strains and can be recommended for routine use.

We are trying to separate molecular species with odd or even numbers of total carbons and double bonds by capillary GC-MS and expect to be able to differentiate $N$. asteroides and $N$. farcinica. A comprehensive analysis of all Nocardia species will be reported in a later paper.

\section{REFERENCES}

1. Alshamaony, L., and M. Goodfellow. 1976. Free mycolic acids as criteria in the classification of Gordona and the 'rhodochrous' complex. J. Gen. Microbiol. 92:183-187.

2. Alshamaony, L., and M. Goodfellow. 1976. Free mycolic acids as criteria in the classification of Nocardia and the 'rhodochrous' complex. J. Gen. Microbiol. 92:188-199.

3. Baba, T., K. Kaneda, E. Kusunose, M. Kusunose, and I. Yano. 1988. Molecular species of mycolic acid subclasses in eight strains of Mycobacterium smegmatis. Lipids 23:1132-1138.

4. Baba, T., K. Kaneda, E. Kusunose, M. Kusunose, and I. Yano. 1989. Thermally adaptive changes of mycolic acids in Mycobacterium smegmatis. J. Biochem. 106:81-86.

5. Biehle, J. R., S. J. Cavalieri, T. Felland, and B. L. Zimmer. 1996. Novel method for rapid identification of Nocardia species by detection of preformed enzyme. J. Clin. Microbiol. 34:103-107.

6. Chun, J., and M. Goodfellow. 1995. A phylogenetic analysis of the genus Nocardia with 16S rRNA gene sequences. Int. J. Syst. Bacteriol. 45:240-245.

7. Collins, M. D., M. Goodfellow, and D. E. Minnikin. 1982. A survey of the structures of mycolic acids in Corynebacterium and related taxa. J. Gen. Microbiol. 128:129-149.

8. Flores, M., and E. Desmond. 1993. Opacification of Middlebrook agar as an aid in identification of Nocardia farcinica. J. Clin. Microbiol. 31:3040-3041.

9. Goodfellow, M. 1971. Numerical taxonomy of some nocardioform bacteria. J. Gen. Microbiol. 69:33-80.

10. Goodfellow, M., P. A. B. Orlean, M. D. Collins, and L. Alshamaony. 1978 Chemical and numerical taxonomy of strains received as Gordona aurantiaca. J. Gen. Microbiol. 109:57-68.

11. Kaneda, K., S. Naito, S. Imaizumi, I. Yano, S. Mizuno, I. Tomiyasu, T. Baba, E. Kusunose, and M. Kusunose. 1986. Determination of molecular species composition of $\mathrm{C}_{80}$ or longer-chain $\alpha$-mycolic acids in Mycobacterium spp. by gas chromatography-mass spectrometry and mass chromatography. J. Clin. Microbiol. 24:1060-1070.

12. Kaneda, K., S. Imaizumi, S. Mizuno, T. Baba, M. Tsukamura, and I. Yano 1988. Structure and molecular species composition of three homologous series of $\alpha$-mycolic acids from Mycobacterium spp. J. Gen. Microbiol. 134: 2213-2229.

13. Kudo, T., K. Hatai, and A. Seino. 1988. Nocardia seriolae sp. nov. causing nocardiosis of cultured fish. Int. J. Syst. Bacteriol. 38:173-178.

14. Lacave, C., M. A. Laneelle, M. Daffe, H. Montrozier, M. P. Rols, and C. Asselineau. 1987. Etude structurale et melaboliques des acides mycoliques de Mycobacterium fortuitum. Eur. J. Biochem. 163:369-378.

15. Lacave, C., M.-A. Laneelle, and G. Laneelle. 1990. Mycolic acid synthesis by Mycobacterium aurum cell free extracts. Biochim. Biophys. Acta 1042:315323.

16. Laurent, F., A. Carlotti, P. Boiron, J. Villard, and J. Freney. 1996. Ribotyping: a tool for taxonomy and identification of the Nocardia asteroides complex species. J. Clin. Microbiol. 34:1079-1082.

17. Minnikin, D. E., M. Minnikin, J. H. Parlett, M. Goodfellow, and M. Magnusson. 1984. Mycolic acid patterns of some species of Mycobacterium. Arch. Microbiol. 139:225-231.

18. Mordarski, M., K. P. Schaal, K. Szyba, G. Pulverer, and A. Tkacz. 1977. Interrelation of Nocardia asteroides and related taxa as indicated by deoxyribonucleic acid reassociation. Int. J. Syst. Bacteriol. 27:66-70.

19. Orchard, V. A., and M. Goodfellow. 1980. Numerical classification of some named strains of Nocardia asteroides and related isolates from soil. J. Gen. Microbiol. 118:295-312.

20. Provost, F., L. Polonelli, S. Conti, P. Fisicaro, M. Gerloni, and P. Boiron. 1995. Use of yeast killer system to identify species of the Nocardia asteroides complex. J. Clin. Microbiol. 33:8-10.

21. Rainey, F. A., S. Klatte, R. M. Kroppenstedt, and E. Stackebrandt. 1995. Dietzia, a new genus including Dietzia maris comb. nov., formerly Rhodococcus maris. Int. J. Syst. Bacteriol. 45:32-36.

22. Ridell, M. 1981. Immunodiffusion studies of some Nocardia strains. J. Gen. Microbiol. 123:69-74.

23. Sathymoorthy, N., N. Qureshi, and K. Takayama. 1985. Purification and characterization of C28-55 fatty acids from Mycobacterium smegmatis. Can. J. Microbiol. 31:214-219.

24. Takayama, K., and L. A. Davidson. 1979. Antimycobacterial drugs that inhibit mycolic acid synthesis. Trends Biochem. Sci. 4:280-282.

25. Tomiyasu, I. 1982. Mycolic acid composition and thermally adaptive changes 
in Nocardia asteroides. J. Bacteriol. 151:828-837.

26. Tsukamura, M. 1977 . Extended numerical taxonomy study of Nocardia. Int. J. Syst. Bacteriol. 27:311-323.

27. Tsukamura, M. 1982. Numerical analysis of the taxonomy of nocardiae and rhodococci; division of Nocardia asteroides sensu stricto into two species and descriptions of Nocardia paratuberculosis sp. nov. Tsukamura (formerly the Kyoto-I group of Tsukamura), Nocardia nova sp. nov. Tsukamura, Rhodococcus aichiensis sp. nov. Tsukamura, Rhodococcus chubuensis sp. nov. Tsukamura, and Rhodococcus obuensis sp. nov. Tsukamura. Microbiol. Immunol. 26:1101-1119.

28. Wallace, R. J., Jr., B. A. Brown, M. Tsukamura, J. M. Brown, and G. O.
Onyi. 1991. Clinical and laboratory features of Nocardia nova. J. Clin. Microbiol. 29:2407-2411.

29. Yano, I., and K. Saito. 1972. Gas chromatographic and mass spectrometric analysis of molecular species of corynomycolic acids from Corynebacterium ulcerans. FEBS Lett. 23:352-356.

30. Yano, I., K. Kageyama, Y. Ohno, M. Masui, E. Kusunose, M. Kusunose, and N. Akimori. 1978. Separation and analysis of molecular species of mycolic acids in Nocardia and related taxa by gas chromatography mass spectrometry. Biomed. Mass Spectrom. 5:14-24.

31. Yano, I., T. Imaeda, and M. Tsukamura. 1990. Characterization of Nocardia nova. Int. J. Syst. Bacteriol. 40:170-174. 